Bangl. J. Vet. Med. (2006). 4 (1): 53-60

\title{
GENOTYPING OF ENTAMOEBA HISTOLYTICA BY REAL-TIME POLYMERASE CHAIN REACTION WITH SYBR GREEN I AND MELTING CURVE ANALYSIS
}

\author{
S. M. M. Rahman ${ }^{1}$, R. Haque, S. Roy and M. M. H. Mondal ${ }^{2}$ \\ International Centre for Diarrheal Disease Research, Bangladesh
}

\begin{abstract}
In this study, for the detection of distinct genotype of E. histolytica of human, a nested Real-Time PCR amplification of SREHP gene using SYBR Green I and melting curve analysis was done. A total of 60 specimens (stool and liver aspirate specimens), which were found Entamoeba histolytica positive by E. histolytica specific ELISA and ssrRNA gene PCR, were selected and the experiment was conducted during the period of July 2003 to June 2004. After melting curve analysis of amplified PCR products from these isolates of stool and liver aspirate specimens, 5 genotypes were found belonging to the melting temperatures $84^{\circ} \mathrm{C}, 83^{\circ} \mathrm{C}, 82^{\circ} \mathrm{C}, 81^{\circ} \mathrm{C}$ and $79^{\circ} \mathrm{C}$. All these 5 genotypes were present in intestinal amoebiasis patients and when the genotypes from intestinal amoebiasis patients were compared with the genotypes of amoebic liver amoebiasis patients, the genotype $84^{\circ} \mathrm{C}$ melting temperature was found to be absent in amoebic liver amoebiasis patients. For both the cases of intestinal and amoebic liver amoebiasis patients the genotype belonging to $83^{\circ} \mathrm{C}$ melting temperature was more prevalent than the other genotypes which suggest that this genotype is more responsible for the development of amoebiasis. In comparison to conventional PCR method where we found 23 different banding patterns, the Real-Time PCR and melting curve analysis method was found to be more reliable for the detection of distinct genotypes of E. histolytica because with this method we found only 5 genotypes. In conclusion, this RealTime PCR using SYBR Green I and melting curve analysis for the genotyping of $E$. histolytica, excludes the need of post PCR manipulations and would be helpful for the rapid detection and screening of E. histolytica genotypes among endemic population and also for the epidemiological study.
\end{abstract}

Key words: Entamoeba histolytica, genotype, diarrhoea, Real-Time PCR, melting curve analysis

\section{INTRODUCTION}

Entamoeba histolytica is a protozoan parasite that causes amoebic colitis and liver abscess in the people of developing countries like India and Bangladesh (Ravdin, 1995; Haque et al., 1997). Global statistics on the prevalence of $E$. histolytica infection indicate that $90 \%$ of infected individuals remain asymptomatic carriers while the other $10 \%$ develop clinically overt disease (Jackson et al., 1985; Haque et al., 1999). This observation might partly be due to the differences in the pathogenic potential of infecting strains (Burch et al., 1991) or due to the variability in the host immune response against amoebic invasion. As the variation in human immune response against amoebic infection is not clearly understood, the genetic differences among E. histolytica need to be determined.

Evidences of intraspecies variation among E. histolytica isolates were first based on isoenzyme analysis (Sargeaunt et al., 1978; Sargeaunt, 1988). After the failure of the isoenzyme analysis due to its less reliability and limited diversity, a polymerase chain reaction (PCR) based-strain typing methods were developed on the basis of polymorphism of different loci of E. histolytica including protein-coding sequences, such as those for the serine rich E. histolytica protein (SREHP) (Li et al., 1992; Kohler and Tannich, 1993) and chitinase (Ghosh et al., 2000), as well as non-protein-coding regions such as rRNA genes (Bhattacharya et al., 1992; Sehgal et al., 1993), a strain specific transcript (Burch et al., 1991), and loci 1-2 and 5-6 (Zaki and Clark, 2001).

Present address: ${ }^{1}$ Corresponding author, Department of Pathology and Parasitology, Dinajpur Government Veterinary College, Basherhat, Dinajpur-5200, Bangladesh, e-mail: smmazidurvet@yahoo.com, ${ }^{2}$ Department of Parasitology, Faculty of Veterinary Science, Bangladesh Agricultural University, Mymensingh-2202, Bangladesh. 
These polymorphic loci have been shown to be potentially useful for the determination of intraspecies variation among E. histolytica and also in investigating the molecular epidemiology of amoebiasis. At present, the most polymorphic gene of E. histolytica is that encoding the serine-rich E. histolytica protein (SREHP or $\mathrm{K}_{2}$ ) a surface antigen with tandem 8-and 12-amino-acid repeats (Stanley et al., 1990; Kohler and Tannich, 1993; Ayeh-Kumi et al., 2001). Ayeh-Kumi et al. (2001) studied the genetic polymorphism among E. histolytica in Bangladesh using the gene encoding for SREHP and they found 34 different banding patterns out of 54 test isolates which indicates extensive intraspecies variation in E. histolytica.

For the study of intraspecies variation or genotyping of $E$. histolytica, different authors used PCR based typing techniques which usually require intensive and laborious post-PCR manipulation, like agarose gel electrophoresis, RFLP analysis, use of hazardous chemical, and carry a potential risk for laboratory contamination. Moreover with these methods, different authors found extensive intraspecies variations among E. histolytica which could not be possible to consider as distinct genotype and also difficult to observe the genotypic relation of $E$. histolytica among different types of amoebic patients. So there is a need to establish an alternative rapid method for genotyping of E. histolytica without the manipulation of hazardous post PCR techniques. To serve the purpose, the present study was designed for the detection of genotypes of E. histolytica on the basis of melting curve analysis using Real-Time PCR with SYBR Green I. The genotypes of E. histolytica were compared between intestinal and amoebic liver amoebiasis patients and a comparison was also studied between the results of conventional PCR method and Real-Time PCR method for genotyping of E. histolytica.

\section{MATERIALS AND METHODS}

This study was carried out in the Laboratory of Parasitology, Laboratory Sciences Division, International Centre for Diarrheal Disease Research, Bangladesh (ICDDR, B), Mohakhali, Dhaka, Bangladesh from July 2003 to June 2004. In this study a total of 60 specimens, which were found positive to Entamoeba histolytica and successfully amplified the Serine-Rich Entamoeba histolytica Protein (SREHP) gene were selected. All these specimens have been selected depending upon different criteria, of which 50 specimens were from stools of intestinal amoebiasis patients and 10 specimens were from liver aspirate of amoebic liver amoebiasis patients from Banghabandhu Sheikh Mujibur Rahman Medical University, Dhaka. Among 50 stool specimens, 32 were from nondiarrhoeic individuals and 18 were from diarrhoeic individuals. 47 stool specimens were collected from the children of Mirpur Slum Area, Dhaka and 3 stool specimens from Matlab (Chandpur) adult subjects.

All the specimens used in this study were first examined by microscopy and with the E. histolytica II stool antigen detection ELISA kit (Techlab Inc., Blacksburg, VA) and then the amplification of small subunit ribosomal RNA gene of E. histolytica was performed for specific diagnosis. The polymorphic SREHP gene of these E. histolytica positive specimens was successfully amplified by using Real-Time PCR with SYBR Green I and then melting curve analysis was done for the genotyping of E. histolytica. Two stool specimens that were negative by microscopy, antigen detection kit, and ssrRNA gene PCR were used as negative controls. DNA isolated from an axenic culture of E. histolytica strain HMI:IMSS was used as the positive control for the SREHP PCR.

\section{Extraction of DNA from stool/liver pus specimens}

Trophozoites and cysts present in the stool and liver aspirates were the source of target DNA. The DNA of these specimens was extracted by using QIAamp ${ }^{\circledR}$ DNA Stool Mini Kit (QIAGEN, Germany) according to the manufacturer's protocol. The materials and methods developed by Clark and Diamond (1993) were used for the extraction of DNA from the culture specimen of E. histolytica.

\section{Nested small subunit rRNA gene PCR}

Two sets of primers were used for the nested small subunit rRNA gene PCR. For the initial PCR, the forward E1 (5'-TTTGTATTAGTACAAA-3') and reverse E2 (5'-GTA[A/G]TATTGATATACT-3') primers which specified a 0.9-kb fragment for both E. histolytica and E. dispar were used. For the nested PCR, the forward Eh1 (5'-AATGGCCCATTCATTCAATG-3') and reverse Eh2 (5'-TTTAGAAACAATGCTTCTCT-3') primers, which specified only E. histolytica, were used. The initial and nested PCRs were performed as previously described (Haque et al., 1998). 


\section{Nested Real-Time PCR of SREHP gene With SYBR Green I}

The DNA specimens, which were found positive for $E$. histolytica by nested ssrRNA gene PCR, were selected for the Real-Time PCR amplification of SREHP gene. The amplification was performed in two phases. In first phase, an initial PCR was performed, which was a conventional type and the forward SREHP-5 (5'GCTAGTCCTGAAAAGCTTGAAGAAGCTG-3') and reverse SREHP-3 (5'-GGACTTGATGCAGCATCAAG GT-3') primers, which amplified a 549-bp fragment of SREHP gene of strain HMI:IMSS (Clark and Diamond, 1993) were used. For the second phase, a nested PCR was performed as Real-Time PCR using SYBR Green I. In second phase, the initial PCR product was used as template and here the forward nSREHP-5 (5'TATTATTATCGTTATCTGAACTACTTCCTG-3') and reverse nSREHP-3 (5'-TGAAGATAATGAAGATGA TGAAGATG-3') primers, which amplified 450-bp fragment located within 549-bp of initial PCR product was used.

The initial PCR was conventional type and a hot start technique was performed. The PCR amplification was carried out in a total of $25 \mu \mathrm{l}$ reaction volume. In case of stool/liver aspirate DNA, about $4 \mu \mathrm{l}$ was mixed with $15.1 \mu \mathrm{l}$ of autoclaved deionized $\mathrm{H}_{2} \mathrm{O}$ and in case of cultured DNA, about $1 \mu \mathrm{l}$ of DNA was mixed with $18.1 \mu \mathrm{l}$ autoclaved deionized $\mathrm{H}_{2} \mathrm{O}$ in $0.2 \mathrm{ml}$ microcentrifuge tube. An amount of $5.9 \mu \mathrm{l}$ of freshly prepared "mastermix" [which contained $2.5 \mu \mathrm{l}$ of $10 \mathrm{X}$ PCR buffer, $1.8 \mu \mathrm{l}$ of $50 \mathrm{mM} \mathrm{MgCl}_{2}, 0.3 \mu \mathrm{l}$ of $25 \mathrm{mM} \mathrm{dNTP}$ mix, $0.3 \mu \mathrm{l}$ of Taq polymerase $(5 \mathrm{U} / \mu \mathrm{l}), 0.5 \mu \mathrm{l}$ of $50 \mathrm{pmol}$ forward primer SREHP-5 and $0.5 \mu \mathrm{l}$ of 50 pmol reverse primer SREHP3 ] was added to the tubes containing DNA and water and then overlaid with one drop of mineral oil (all reagents were obtained from Invitrogen ${ }^{\mathrm{TM}}$, USA). Then the tubes were taken in iCycler Thermal Cycler and the activation of Taq polymerase was done by a initial denaturation at $94^{\circ} \mathrm{C}$ for 3 minutes and then 40 cycles of PCR were performed with denaturation at $94^{\circ} \mathrm{C}$ for $60 \mathrm{sec}$, annealing at $45^{\circ} \mathrm{C}$ for $60 \mathrm{sec}$ and extension at $72^{\circ} \mathrm{C}$ for $90 \mathrm{sec}$. After completion of 40 cycles, a final extension was done at $72^{\circ} \mathrm{C}$ for 5 minutes and the product was maintained at $4^{\circ} \mathrm{C}$ until the nested Real-Time PCR was done.

Real time PCR amplification was done by taking the initial PCR product of SREHP gene as a template. In This Real-Time PCR total reaction volume was of $25 \mu \mathrm{l}$. An amount of $1.0 \mu \mathrm{l}$ of diluted initial PCR product (1:50) was added to $11.0 \mu \mathrm{l}$ of deionized water in $0.2 \mathrm{ml}$ well of experimental PCR plate. An amount of $13.0 \mu \mathrm{l}$ of freshly prepared "mastermix" (which contained $12.5 \mu$ l of 2 X iQ SYBR Green Supermix, $0.25 \mu$ l of 50 pmol forward primer nSREHP-5 and $0.25 \mu \mathrm{l}$ of 50 pmol reverse primer nSREHP-3) was added to the well containing water and DNA (the reagent for Real-Time PCR was obtained from Bio-Rad Laboratories, Inc.). The other steps were similar to the initial PCR of SREHP gene except the annealing temperature which raised from $45^{\circ} \mathrm{C}$ to $55^{\circ} \mathrm{C}$. SYBR Green I is a double-stranded DNA binding dye and when it binds to double-stranded DNA, the fluorescence emission occurs which is used for the visualization of amplified product. During Real-Time PCR of SREHP gene with SYBR Green I, the amplification of each DNA specimen was determined by observing the fluorescence emission curves (Fig. 1). These curves were produced due to binding of SYBR Green I to the PCR product and the fluorescence reading were taken after each extension step of Real-Time PCR. The fluorescence emission increases due to the increase cycle of PCR.

\section{Melting Curve Analysis}

After completion of 40 cycles PCR amplification, the PCR products were melted by raising the temperature from $40^{\circ} \mathrm{C}$ to $95^{\circ} \mathrm{C}$ at a rate of $1^{\circ} \mathrm{C} / \mathrm{min}$. The iCycler iQ software displayed the data collected during melt curve analysis as $\mathbf{- d F} / \mathbf{d T}$ vs Temperature (Fig. 2). As a result melting temperatures were derived from melting peaks by melting curve analysis of the amplified DNA specimens. PCR products were analyzed on agarose gels to observe different types of banding patterns and to compare these patterns with melting temperatures. To this aim, products amplified on the iCycler Thermal Cycler were recovered from PCR plates, mixed with loading buffer, and loaded onto $1.3 \%$ agarose gels in $1 \times$ TBE (Tris-borate-EDTA) buffer. The gels were stained with ethidium bromide.

\section{Statistical Analysis}

Statistical analysis was done by the software "EP info" to compare the genotypes of $E$. histolytica between intestinal amoebiasis patients and amoebic liver amoebiasis patients 


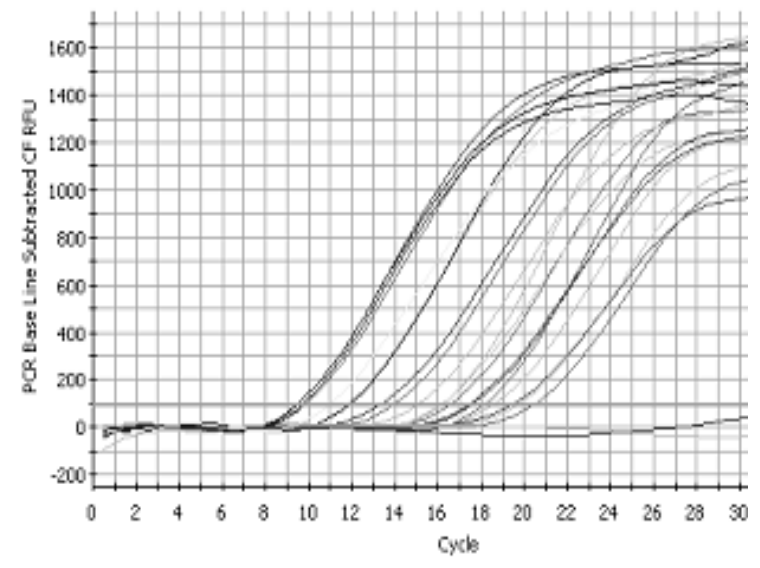

Fig. 1. Amplification of SREHP gene of E. histolytica with SYBR Green I using primers $n S R E H P-5$ and $n S R E H P-3$. Amplification of the SREHP gene can be determined by observing the fluorescence emission curves. The fluorescence curves which exceed the threshold bar represent the amplified SREHP gene of E. histolytica. The DNA from nonamoebic stool did not amplified and the fluorescence curves remained below the threshold bar.

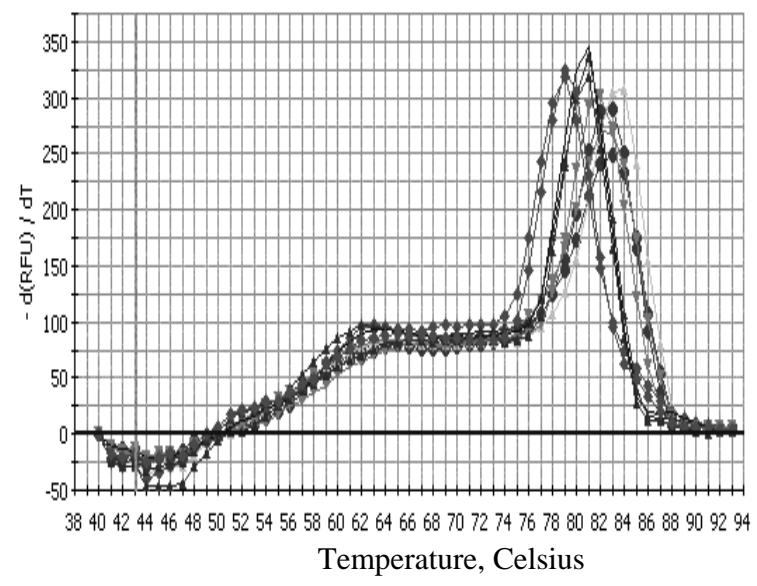

Fig. 2. Different types of melting peak of E. histolytica for SREHP gene amplification with SYBR Green I.

This graph represents the amplified DNA products as distinct melting peaks with specified melting temperatures. The melting temperatures are $84^{\circ} \mathrm{C}, 83^{\circ} \mathrm{C}$, $82^{\circ} \mathrm{C}, 81^{\circ} \mathrm{C}$ and $79^{\circ} \mathrm{C}$ and each melting temperature is considered as a genotype.

\section{RESULTS AND DISCUSSION}

\section{Genotypes of E. histolytica}

The SREHP gene was amplified from $60 \mathrm{E}$. histolytica isolates (collected from stool specimens of symptomatic and asymptomatic individuals and from liver aspirates of amoebic liver amoebiasis patients) by Real-Time PCR with SYBR Green I. The amplified products were then melted and by melting curve analysis five different melting temperatures e.g. $84^{\circ} \mathrm{C}, 83^{\circ} \mathrm{C}, 82^{\circ} \mathrm{C}, 81^{\circ} \mathrm{C}$ and $79^{\circ} \mathrm{C}$ were found (Fig. 2). Each melting temperature was considered as a genotype. As a result, five genotypes; genotype-I, genotype-II, genotype-III, genotype-IV and genotype- $\mathrm{V}$ were found for the melting temperature $84^{\circ} \mathrm{C}, 83^{\circ} \mathrm{C}, 82^{\circ} \mathrm{C}, 81^{\circ} \mathrm{C}$ and $79^{\circ} \mathrm{C}$ respectively (Table 1$)$.

Table 1. Different melting temperatures of E. histolytica isolates from specimens of stool and liver abscess aspirates

\begin{tabular}{|c|c|c|c|c|}
\hline Total number of isolates & $\begin{array}{l}\text { Melting temperatures } \\
(\mathrm{Tm})^{\circ} \mathrm{C}\end{array}$ & Genotypes & $\begin{array}{l}\text { Number of } \\
\text { isolates }\end{array}$ & $\begin{array}{l}\text { Percentage of } \\
\text { isolates (\%) }\end{array}$ \\
\hline \multirow{5}{*}{60} & 84 & Genotype-I & 12 & 20 \\
\hline & 83 & Genotype-II & 27 & 45 \\
\hline & 82 & Genotype-III & 09 & 15 \\
\hline & 81 & Genotype-IV & 08 & 13.33 \\
\hline & 79 & Genotype-V & 04 & 06.67 \\
\hline $\begin{array}{l}\text { Positive control } \\
\text { (HM1: IMSS) }\end{array}$ & 83 & Genotype-II & 01 & - \\
\hline $\begin{array}{l}\text { Negative control } \\
\text { (Non-amoebic stool) }\end{array}$ & Not amplified & - & 02 & - \\
\hline
\end{tabular}


The melting temperature for each peak is dependent on the GC/AT ratio, length, and nucleotide sequence of the PCR product (Ririe et al., 1997; Nicolas et al., 2002). Based on this principle, in this study we found 5 genotypes belonging to 5 different melting temperatures. Tanriverdi et al. (2002) for the genotyping of C. parvum, Amar et al. (2003) for the geotyping of G. duodenalis, Nicolas et al. (2002) for the differentiation of Leishmania species, Fujigaki et al. (2004) for the genotyping of Hepatitis C virus used Real-Time PCR with SYBR Green I and melting curve analysis. Their genotyping methods and results on the basis of melting curve analysis strongly support the present study for the genotyping of E. histolytica using Real-Time PCR and melting curve analysis. Among $60 \mathrm{E}$. histolytica isolates from specimens of stool and liver abscess aspirates, the genotype-II was found to be more prevalent (45\%) than the genotype-I (20\%), genotype-III (15\%), genotype-IV (13.33\%) and genotype-V (6.67\%) (Table 1).

\section{Genotypes of intestinal and amoebic liver amoebiasis patients}

Among 50 E. histolytica isolates of intestinal amoebiasis patients, 20 (40\%) isolates were to the genotype-II. On the other hand, among $10 \mathrm{E}$. histolytica isolates of amoebic liver amoebiasis patients, 7 (70\%) isolates were to the genotype-II (Table 2). When the genotype-II was compared between the intestinal and amoebic liver amoebiasis patients, it was found that the genotype-II was more prevalent in amoebic liver amoebiasis patients, which was borderline significant $(\mathrm{p}=0.09)$.

Table 2. Differences of genotypes among E. histolytica isolates of intestinal and amoebic liver amoebiasis patients

\begin{tabular}{|llllll|}
\hline Genotypes of E. histolytica & $\begin{array}{l}\text { Genotypes from stool isolates } \\
(\mathrm{n}=50)\end{array}$ & & \multicolumn{2}{l}{$\begin{array}{l}\text { Genotypes from liver abscess isolates } \\
(\mathrm{n}=10)\end{array}$} \\
\cline { 2 - 3 } & No. & & No. & $\%$ \\
\hline Genotype-I & 12 & 24 & 0 & 0 \\
Genotype-II & 20 & 40 & 7 & 70 \\
Genotype-III & 08 & 16 & 1 & 10 \\
Genotype-IV & 07 & 14 & 1 & 10 \\
Genotype-V & 03 & 06 & 1 & 10 \\
\hline
\end{tabular}

$\mathrm{n}=$ Number of stool isolates / liver abscess isolates.

Table 3. Genotypes of E. histolytica isolates from stool specimens of asymptomatic (nondiarrhoeal) and symptomatic (diarrhoeal) individuals

\begin{tabular}{|llcllc|}
\hline Genotypes of E. histolytica & \multicolumn{2}{l}{$\begin{array}{l}\text { Genotypes from asymptomatic } \\
\text { (nondiarrhoeal) patients }(\mathrm{n}=32)\end{array}$} & & \multicolumn{2}{l|}{$\begin{array}{l}\text { Genotypes from symptomatic } \\
\text { (diarrhoeal) patients }(\mathrm{n}=18)\end{array}$} \\
\cline { 2 - 3 } \cline { 5 - 6 } & No. & & No. & $\%$ \\
\hline Genotype-I & 06 & & 6 & 33.33 \\
Genotype-II & 14 & 43.75 & & 33.33 \\
Genotype-III & 05 & 15.62 & 3 & 16.67 \\
Genotype-IV & 06 & 18.75 & 1 & 05.56 \\
Genotype-V & 01 & 3.13 & 2 & 11.11 \\
\hline
\end{tabular}

$\mathrm{n}=$ Number of stool isolates. 
All the 5 genotypes were present in intestinal amoebiasis patients but in case of amoebic liver amoebiasis patients the genotype-I was absent which was statistically insignificant ( $p>0.05)$, however we tested 10 isolates of E. histolytica from amoebic liver amoebiasis patients. Such interesting findings need to be studied further in future with more samples.

Out of 32 stool isolates of E. histolytica from asymptomatic individuals, 14 (43.75\%) isolates were to the genotype-II and out of 18 isolates from diarrhoeal patients, 6 (33.33\%) isolates were to the genotype-II. When the genotype-II from asymptomatic and symptomatic patients was compared with the genotype-II of amoebic liver amoebiasis patients, it was found insignificant ( $\mathrm{p}>0.05$ ) (Table 3).

\section{Comparison between the melting temperatures and nested SREHP PCR product (undigested) sizes for the genotyping of E. histolytica}

For the genotyping of E. histolytica, a comparison was studied between the melting curve analysis method and the traditional PCR based typing method. For this, all the undigested nested SREHP PCR products belonging to five melting temperatures were run by agarose gel electrophoresis (Fig. 3) and as a result 23 different banding patterns were found (Table 4) which indicated extensive genetic variation among E. histolytica isolates.

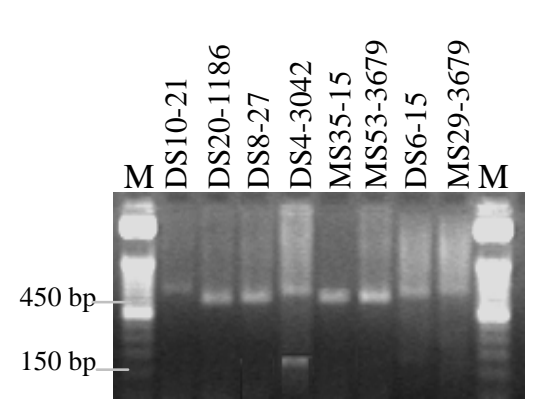

A

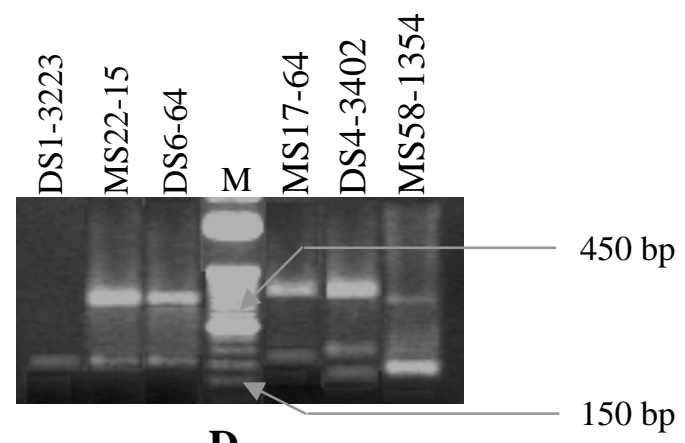

D

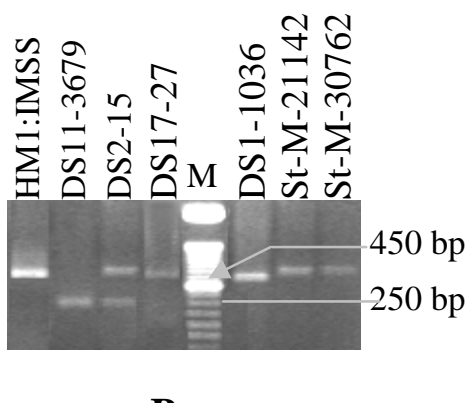

B

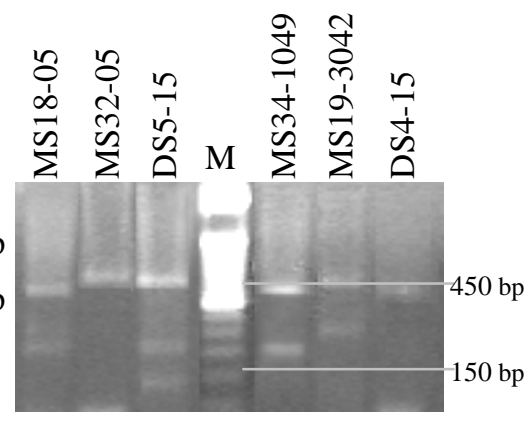

C

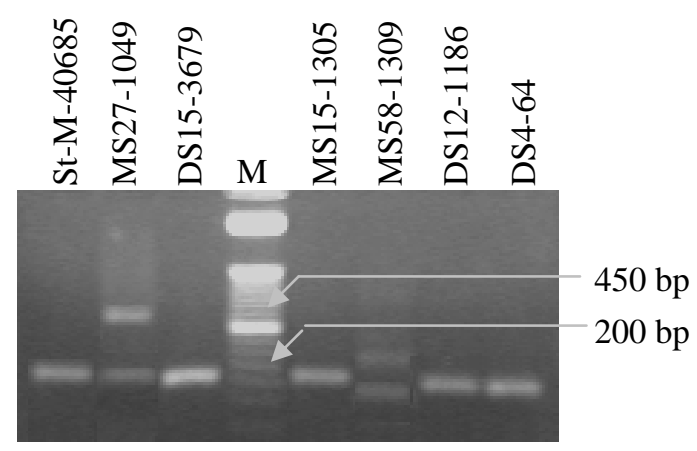

$\mathbf{E}$

Fig. 3. Gel photograph of nested SREHP PCR products (undigested) from E. histolytica isolates belonging to the melting temperature $84^{\circ} \mathrm{C}(\mathrm{A}), 83^{\circ} \mathrm{C}(\mathrm{B} \& \mathrm{C}), 82^{\circ} \mathrm{C}(\mathrm{D}), 81^{\circ} \mathrm{C}$ and $79^{\circ} \mathrm{C}(\mathrm{E})$. After the Real-Time PCR amplification of SREHP gene and melting curve analysis, the PCR products belonging to the different melting temperatures were run in a 1.3\% agarose gel. Isolate designations are shown at the top. In gel photograph B, HM1: IMSS strain represents the control DNA amplification from culture. Lane M represents 50 base pair DNA marker (Invitrogen ${ }^{\circledR}$ ). 
Ghosh et al. (2000), Zaki and Clark (2001), Ayeh-Kumi et al. (2001) and Haghighi et al. (2002) also found extensive genetic variations among E. histolytica isolates by using traditional PCR based methods. But in this study, we found 5 distinct genotypes using Real-Time PCR and melting curve analysis.

Table 4. Comparison between the melting temperatures and nested SREHP PCR product (undigested) sizes

\begin{tabular}{|c|c|c|c|c|}
\hline Genotypes & $\begin{array}{l}\text { Melting temperature } \\
\left({ }^{\circ} \mathrm{C}\right)\end{array}$ & $\begin{array}{l}\text { Nested SREHP- PCR } \\
\text { product Size (bp) }\end{array}$ & Pattern No. & $\begin{array}{l}\text { Frequency of } \\
\text { band pattern }\end{array}$ \\
\hline \multirow{3}{*}{ Genotype-V } & 79 & 120 & 1 & 1 \\
\hline & & 140 & 2 & 1 \\
\hline & & 170 & 3 & 2 \\
\hline \multirow[t]{4}{*}{ Genotype-IV } & 81 & 180 & 4 & 3 \\
\hline & & 190 & 5 & 3 \\
\hline & & 240,140 & 6 & 1 \\
\hline & & 430,180 & 7 & 1 \\
\hline \multirow[t]{5}{*}{ Genotype-III } & 82 & 450,200 & 8 & 5 \\
\hline & & $450+, 210$ & 9 & 1 \\
\hline & & 240 & 10 & 1 \\
\hline & & 200 & 11 & 1 \\
\hline & & $450+, 240,180$ & 12 & 1 \\
\hline \multirow[t]{9}{*}{ Genotype-II } & 83 & 410 & 13 & 2 \\
\hline & & 440 & 14 & 1 \\
\hline & & 450 & 15 & 14 \\
\hline & & 410,230 & 16 & 3 \\
\hline & & 450,260 & 17 & 3 \\
\hline & & $450,230,130$ & 18 & 1 \\
\hline & & 400 & 19 & 1 \\
\hline & & $450,220,190$ & 20 & 1 \\
\hline & & 250 & 21 & 1 \\
\hline \multirow[t]{2}{*}{ Genotype-I } & 84 & $450+$ & 22 & 11 \\
\hline & & $450+, 160$ & 23 & 1 \\
\hline
\end{tabular}

Moreover, the traditional PCR based typing techniques require more time, intensive and laborious post-PCR manipulations (like agarose gel electrophoresis and RFLP analysis), make use of hazardous chemicals, and carry a potential risk for laboratory contamination. On the other hand, this Real-Time PCR assay has a considerable advantage over the previously reported assay because of the speed of analysis and excluding the post PCR manipulation. Thus this Real-Time PCR assay with SYBR Green I and melting curve analysis would be helpful for the rapid screening of genotypes of E. histolytica among endemic population and also for the epidemiological studies. This method of genotyping of E. histolytica by Real-Time PCR with SYBR Green I and melting curve analysis should be compared in future with the other method of Real-Time PCR with different probes and dye to observe different genotypic variations. Each genotype (for each melting temperature) found in this study should be sequenced in future as within each genotype different banding pattern of PCR products were found. 


\section{REFERENCES}

1. Amar CFL, Dear PH and McLauchlin J (2003). Detection and genotyping by real-time PCR/FRLP analyses of Giardia duodenalis. Journal of Medical Microbiology 52: 681-683.

2. Ayeh-Kumi PF, Ali IKM, Lockhart LA, Gilchrist CA, Petri WAJr and Haque R (2001). Entamoeba histolytica: Genetic diversity of clinical isolates from Bangladesh as demonstrated by polymorphisms in the Serine-Rich Gene. Experimental Parasitology 99: 80-88.

3. Bhattacharya S, Bhattacharya A and Diamond LS (1992). Entamoeba histolytica extrachromosomal circular ribosomal DNA: analysis of clonal variation in a hypervariable region. Experimental Parasitology 74: 200-204.

4. Burch DJ, Li E, Reed S, Jackson TFHG and Stanley SLJr (1991). Isolation of a strain -specific Entamoeba histolytica cDNA clone. Journal of Clinical Microbiology 29: 696-701.

5. Clark CG and Diamond LS (1993). Entamoeba histolytica: a method for isolate identification. Experimental Parasitology 77: 450-455.

6. Fujigaki H, Takemura M, Takahashi K, Yamada Y, Fujii H, Wada H, Saito K, Ohnishi H and Seishima M (2004). Genotyping of hepatitis C virus by melting curve analysis with SYBR Green I. Annals of Clinical Biochemistry 41 (Pt 2): $130-132$.

7. Ghosh S, Frisardi M, Ramirez AL, Descoteaux S, Sturm RK, Newton SOA, Santos PJI, Ganguly C, Lohia A, Reed S and Samuelson J (2000). Molecular epidemiology of Entamoeba spp.: evidence of a bottleneck (Demographic sweep) and transcontinental spread of diploid parasites. Journal of Clinical Microbiology 38: 3815-3821.

8. Haque R, Faruque ASG, Hahn P, Lyerly DM and Petri WAJr (1997). Entamoeba histolytica and Entamoeba dispar infection in children in Bangladesh. Journal of Infectious Diseases 175: 734-736.

9. Haque R, Ali IKM, Akther S and Petri WAJr (1998). Comparison of PCR, isoenzyme analysis and antigen detection for diagnosis of Entamoeba histolytica infection. Journal of Clinical Microbiology 36: 449-452.

10. Haque R, Ali IKM and Petri WAJr (1999). Prevalence and immune response of Entamoeba histolytica infection in preschool children in Bangladesh. American Journal of Tropical Medicine and Hygiene 60: 1031-1034.

11. Haghighi A, Kobayashi S, Takeuchi T, Masuda G and Nozaki T (2002). Remarkable genetic polymorphism among Entamoeba histolytica isolates from a limited geographic area. Journal of Clinical Microbiology 40: 4081-4090.

12. Jackson TFHG, Gathiram V and Simjee AE (1985). Seroepidemiological study of antibody responses to the zymodemes of Entamoeba histolytica. Lancet 1: 716-719.

13. Kohler S and Tannich E (1993). A family of transcripts $\left(\mathrm{K}_{2}\right)$ of Entamoeba histolytica contains polymorphic repetitive regions with highly conserved elements. Molecular and Biochemical Parasitology 59: 49-58.

14. Li E, Kunz-Jenkins C and Stanley SLJr (1992). Isolation and characterization of genomic clones encoding a serine-rich Entamoeba histolytica protein. Molecular and Biochemical Parasitology 50: 355-357.

15. Nicolas L, Milon G and Prina E (2002). Rapid differentiation of Old World Leishmania species by LightCycler polymerase chain reaction and melting curve analysis. Journal of Microbiological Methods 51: $295-299$.

16. Ravdin JI (1995). Amoebiasis. State-of-the-art clinical article. Clinical Infectious Diseases 20: 1453-1466.

17. Ririe KM, Rasmussen RP and Wittwer CT (1997). Product differentiation by analysis of DNA melting curves during the polymerase chain reaction. Analytical Biochemistry 245: 154-160.

18. Sargeaunt PG, Williams JE and Grene JD (1978). The differentiation of invasive and non-invasive Entamoeba histolytica by isoenzyme electrophoresis. Transactions of the Royal Society of Tropical Medicine and Hygiene 72: 519521.

19. Sargeaunt PG (1988). Zymodemes of Entamoeba histolytica. In “Amebiasis: Human Infection by Entamoeba histolytica” (Ravdin, J. Ed.), pp 370-387, Wiley, New York.

20. Sehgal D, Bhattacharya A and Bhattacharya S (1993). Analysis of a polymorphic locus present upstream of rDNA transcription units in the extrachromosomal circle of Entamoeba histolytica. Molecular and Biochemical Parasitology 62: $129-130$.

21. Stanley SLJr, Becker A, Kunz-Jenkins C, Foster L and Li E (1990). Cloning and expression of a membrane antigen of Entamoeba histolytica possessing multiple tandem repeats. Proceedings of the National Academy of Sciences of the United States of America 87: 4976-80.

22. Tanriverdi S, Tanyeli A, Baslamish F, Koksal F, Kihnc Y, Feng X, Batzer G, Tzipori S and Widmer G (2002). Detection and genotyping of oocysts of Cryptosporidium parvum by Real-Time PCR and Melting Curve Analysis. Journal of Clinical Microbiology 40: 3237-3244.

23. Zaki M and Clark CG (2001). Isolation and characterization of polymorphic DNA from Entamoeba histolytica. Journal of Clinical Microbiology 39: 897-905. 